\title{
Impact of High Performance Human Resource Practices on Employees' Job Performance in Leather Goods Manufacturing Companies at Vellore District
}

\author{
M. Kaveri and Dr.G. Prabakaran
}

\begin{abstract}
This study aims at exploring the impact of high performance HR practices on employees' job performance. The study sought to establish the effect of job design, training and development, motivation, supervisory support, working environment and compensation on employees' job performance in Leather goods manufacturing companies at Vellore district. The research design used was descriptive survey research design. Stratified proportionate random sampling was used. Data was collected using questionnaires and analyzed by using descriptive statistics, correlation and regression analysis, chi-square and Friedman test was done to establish the relationship between various HRM practices and employees' job performance. Data was presented in the form of tables. Based on the findings, job design, supervisory support and work environment are having a positive and significant relationship with employees' job performance and training and development, motivation and compensation are not having a significant relationship with employees' job performance. Conclusions as well as implications are discussed.
\end{abstract}

Keywords--- High Performance Human Resource Practices, Employees' Job Performance \& Leather Goods Manufacturing Companies at Vellore District

\section{INTRODUCTION}

L EATHER industry displayed its significance in world's market with tremendous contribution to the Indian economy. The entry of global players in Leather Industry has created huge challenges to the Indian companies [23]. Owing to that Indian Leather companies were forced to adopt and implement innovative changes in their HR practices. They have realized that in today's competitive business milieu, human Resource practices is the one which forms the framework for the culture in the business management; create awareness towards the need to achieve the business goals by the employees in the best possible and ethical manner. It is widely accepted that employees constitute a vital part of

M. Kaveri, Doctoral Research Scholar, Department of Business Administration, Government Arts College, Dharmapuri, Tamil Nadu, India.

Dr.G. Prabakaran, Assistant Professor, Department of Business Administration, Government Arts College, Dharmapuri, Tamil Nadu, India. organization resource, with the potential to improve the organization's viable modest advantage [19]. Consequently, human resource manager in Leather Industries would target potential work force and would lay stress on skill development, technical development and effective job performance by adopting effective human resource practices. The keyrefrain of this precise research is to observe the relationship between the high performance HR practices such as job design, training and development, motivation, supervisory support, working environment and compensation on employees' job performance in Leather goods manufacturing companies at Vellore district. It also analyses the impact of high performance HR practices on employees' job performance.

\subsection{Statement of the Problem}

In the present competitive scenario, it is mandatory for the Leather companies to concentrate on the activities such as assimilating new technologies, continuous emphasis on product development and design up gradation. But due to the limited scope for mobilizing funds through private placements and public issues, limited availability of bank loans and strict international standards it is difficult for the Leather companies to compete globally. The only strength has in by the Leather companies is that proficient human resource. Therefore the leather companies were decidedly and vastly spellbound on the effectual human resource practices to have a resourceful job performance of the employees. In particular HR practices such as job design, training and development, motivation, supervisory support, working environment and compensationare widely believed to improve the performance of employee as well as organizations. This study focuses on the impact that high performance human resource practices have on improvement of employee's job performance.

\subsection{Research Questions (RQ)}

Q1: Is there any association between high performance HR practices and employees' job performance?

Q1: Do high performance HR practices have any impact on employees' job performance?

\subsection{Objectives of the Study}

The main purpose of the study was to identify the impact of high performance HR practices on employees' performance. The specific objectives of this study are 
- To determine the influence ofjob design on employees' job performance in Leather goods manufacturing companies at Vellore District.

- To determine the influence of training and development on employees' job performance in Leather goods manufacturing companies at Vellore District.

- To determine the influence of motivation on employees' job performance in Leather goods manufacturing companies at Vellore District.

- To determine the influence of supervisory support on employees' job performance in Leather goods manufacturing companies at Vellore District.

- To determine the influence of work environment on employees' job performance in Leather goods manufacturing companies at Vellore District.

- To determine the influence of compensation on employees' job performance in Leather goods manufacturing companies at Vellore District.

\subsection{Significance of the Study}

This study is very prolific for HR managers in Leather Industries as they would get a clear idea about the relationship of HR practices and employees' job performance, as a result they can have more productive employees and can retain efficient employees in their organization. It has both practical and theoretical significance. It advances knowledge and understanding of how HR practices affect employees' job performance in Leather Goods manufacturing companies at Vellore district; and it may also be used to assist other manufacturing organizations in formulating effective HR practices to increase performance of the employees.

\subsection{Scope \& Limitations of the Study}

The study was conducted within Leather goods manufacturing companies at Vellore district. Only the high performance HR practices such as job design, training and development, motivation, supervisory support, working environment and compensation influencing employees' job performance was considered for the study. The study is limited to high performance HR practices affecting employees' job performance in Leather Goods manufacturing companies at Vellore district and it does not consider tanning and finishing Leather companies. All findings are based on the information provided by the respondents, and are subject to the potential bias and prejudice of the people involved.

\section{LITERATURE SURVEY}

\subsection{Impact of HR Practices on Employees' Job Performance}

Impact of HRM on employees' job performance depends upon worker's response to HRM practices, so the impact will move in direction of the perception of HRM practices by the employee [14]. By adopting best practices in selection, inflow of best quality of skill set will be inducted adding value to skills inventory of the organization [16]. Use of best HR practices shows a stronger association with firm's productivity in high growth industry [8]. Ample of the existing research on the relationship between HR practices and performance of the employees and proposed that there is a positive relationship between the HR practices on employee job performance and also revealed that in the competitive environment of modern era organizations are persistently improving performance of their employees by improving HR practices [11].

\subsection{Relationship of HR Practices on Employees' Job Performance}

\section{- Job Design}

Job design is the functions of arranging task, duties and responsibilities in to an organizational unit of work [18]. In particular HRM practices such as employee participation and empowerment, job redesign, team-based production systems, extensive employee training and performance-contingent incentive compensation are widely believed to improve the performance of organizations [19].

\section{- Training and Development}

Training programs helps in making acquaintance of employees with more advance technology and attaining robust competencies and skills in order to handle the functions and basics of newly introduced technical equipment [20]. Training not only mentally develops the employee but also prepare them to make better their health in order to be with active mind and more productive thought for the organization [7]. Improving employee's self-efficacy at work will also assist in pushing their performance to an improved and effective level and increasing their momentum on their own behalf. This one also is achievable through adding it into the contents of training program[1] is of the opinion that for every employee to perform well there is the need for constant training and development. The right employee training, development and education provide big payoffs for the employer in increased productivity, knowledge, loyalty, and contribution to general growth of the firm

\section{- Motivation}

Motivation plays an important role in performance and other activities and as such the manager should know what motivation is and how subordinates can are motivated towards performance. When employees have high autonomy, receive feedback about their performance, and have an important, identifiable piece of work to do which requires skill variety, they may experience feelings of happiness and therefore intrinsic motivation to keep performing well [15]. A motivated employee is more likely to output more to the benefit of the organization [22]. They continue to argue that most of the successful people are around, have been proved to be very efficient time managers. A reward strategy can develop teamwork. Lawler states, "Reward systems can support change and motivate people to accept change and gain the skills that fit the changing nature of the business" [2].

\section{- Supervisory Support}

It is the duty of supervisors to ensure that employee job performance is at maximum potential, it would be advantageous for managers in all trades and industry sectors worldwide to understand what types of employee-supervisor interactions are associated with employee job performance. If more work is delegated and responsibility is increased, employees are likely to see it as a sign of appreciation and 
trust in their performance, which translates to a boost in selfesteem and motivation to perform [13]. Perception of supervisors has an impact on many employee outcomes related to production. They went on to explain that perception of a supervisor has a positive correlation with motivation and a negative correlation with stress in employees [12].

\section{- Work Environment}

Work environment is considered to be an important factor affected by transformational leadership and affecting performance. It is composed of all factors related to job and organization, which influence the relationship between employees, their job and the organization [3]. Organizations in order to boost productivity design work environment in a way that satisfies employees [5]. Social, organizational and physical context serve as the impetus for tasks and activities, and considerably influence workers' performance and work output [21].

\section{- Compensation}

The general purposes of the compensation policy covers respecting employees' performance, maintaining a competitive labor market conditions, maintain justice employee salaries, motivating employee performance and reduce employee turnover[26]. Compensation performance is the result work of employee because it is the strongest link for the planned goal and economy [7]. Providing respectful compensation to the employees of an organization has soothing effect of both organization and employees' performance.

\subsection{Theoretical Framework}

In the literature review, it has been observed that employees' job performance has an impact on different variables like job design, training and development, motivation, supervisory support, working environment and compensation. Organizational performance ultimately depends upon employees' job performance and human resource practices are the tool to improve employees' job performance. The following theoretical framework has been formulated to depict a relationship between different $\mathrm{HR}$ practices and employees' job performance.

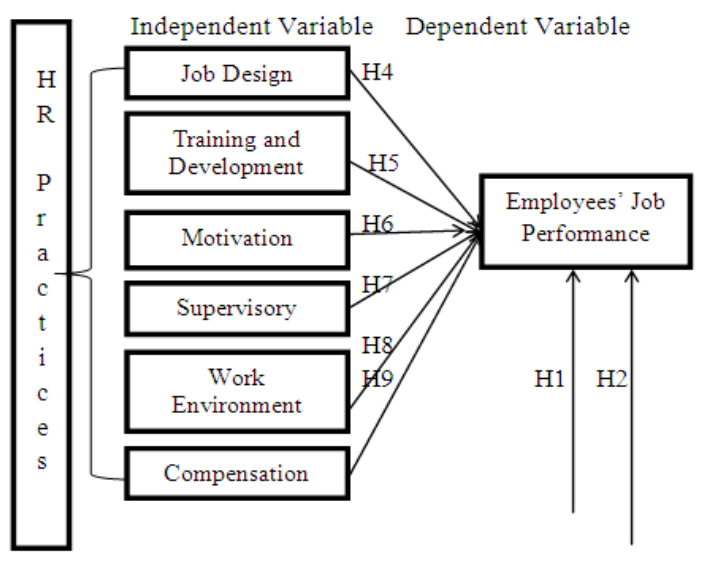

\subsection{Hypotheses Development}

On the basis of the various factors of high performance HR practices affecting employees' job performance, the following hypotheses are developed for the study:-

H1: HR Practices have significant association with employees' job performance.

H2: HR Practices have significant impact on employees' job performance.

H3: Personal factors have significant association with employees' job performance.

H4: Job Design is positively related to employee job performance.

H5: Training and Development is positively related to employee job performance.

H6: Motivation is positively related to employee job performance.

H7: Supervisory Support is positively related to employee job performance.

H8: Work Environment is positively related to employee job performance.

H9: Compensation is positively related to employee job performance.

H10: No significant difference between the six HR practices

\section{METHOdOLOGY OF THE STUDY}

This study scrutinized the relationship of job design, training and development, motivation, supervisory support, working environment and compensation with employees' job performance in Leather goods manufacturing companies at Vellore district. It is basically a descriptive study which was aimed at gaining in depth understanding of the effect that various high performance Human resource practices have on employees' job performance. The target population of this study consists of those employees working in selected 10 Leather goods manufacturing companies at Vellore district. The sample size was 200 employees. Stratified proportionate random sampling has been used to collect data from the employees. Here the employees were divided into strata based on departments in which they working, and therefore respondents were selected randomly on proportionate basis for the various departments. The data collected is based on both primary and secondary data source. Primary data were collected through a personally administered structured questionnaire from the employees working in Leather goods manufacturing companies at Vellore district. The questionnaire consists of different questions on six HRM dimensions such as job design, training and development, motivation, supervisory support, working environment and compensation and also questions related to employees' job performance. The questionnaire was developed by using a five point Likert scale, whereas $1=$ dissatisfied, $2=$ somehow satisfied, $3=$ satisfied, $4=$ moderately satisfied, $5=$ highly satisfied. The secondary data used in the study have been collected from related journals, books, newspapers and internet, etc. In this study, some statistical measures such as descriptive statistics, correlation, chi-square, and regression and Friedman test were used to examine relationship and 
impact of high performance HR practices on employee's job performance.

\section{ANALYSIS AND FINDINGS}

\subsection{Reliability Test}

Reliability tests were conducted on the independent and dependent variables which are job design, compensation, motivation, working environment, training and development, supervisory support and employees' job performance by using the Cronbach's alpha. It may be mentioned that its value varies from 0 to 1 but the satisfactory value is required to be more than 0.6 for the scale to be reliable [6] [17]. As a result, Cronbach's alpha for the job design (0.877); training and development (0.912); motivation (0.835); supervisory support (0.643); work environment (0.871); compensation (0.829) and finally, for employees' job performance (0.857).

\section{Table I}

\begin{tabular}{|l|r|r|}
\hline \multicolumn{1}{|c|}{ Scale } & \multicolumn{1}{|c|}{$\begin{array}{c}\text { No. of } \\
\text { items }\end{array}$} & $\begin{array}{c}\text { Cronbach's } \\
\text { Alpha }(\alpha)\end{array}$ \\
\hline Job design & 5 & 0.877 \\
\hline Training and development & 5 & 0.912 \\
\hline Motivation & 5 & 0.835 \\
\hline Supervisory support & 5 & 0.643 \\
\hline Work environment & 5 & 0.871 \\
\hline Compensation & 5 & 0.829 \\
\hline $\begin{array}{l}\text { Employees' job } \\
\text { performance }\end{array}$ & 5 & 0.857 \\
\hline
\end{tabular}

Source: Primary Data

\subsection{Descriptive Statistics}

Table II

\begin{tabular}{|c|c|c|c|c|c|}
\hline Variables & $\mathrm{N}$ & Minimum & Maximum & Mean & $\begin{array}{c}\text { Std. } \\
\text { Deviation }\end{array}$ \\
\hline Gender & 200 & 1 & 2 & 1.57 & .496 \\
\hline Age & 200 & 1 & 5 & 2.66 & 1.201 \\
\hline $\begin{array}{l}\text { Educational } \\
\text { Qualification }\end{array}$ & 200 & 1 & 5 & 2.14 & 1.045 \\
\hline Job position & 200 & 1 & 5 & 2.71 & 1.398 \\
\hline Experience & 200 & 1 & 5 & 2.43 & 1.105 \\
\hline Income & 200 & 1 & 5 & 2.63 & 1.145 \\
\hline Job Design & 200 & 6 & 25 & 15.75 & 4.892 \\
\hline $\begin{array}{l}\text { Training and } \\
\text { Development }\end{array}$ & 200 & 5 & 25 & 15.59 & 5.082 \\
\hline Motivation & 200 & 7 & 25 & 15.80 & 4.844 \\
\hline $\begin{array}{l}\text { Supervisory } \\
\text { Support }\end{array}$ & 200 & 7 & 22 & 15.55 & 3.223 \\
\hline $\begin{array}{l}\text { Work } \\
\text { Environment }\end{array}$ & 200 & 6 & 25 & 16.23 & 5.017 \\
\hline Compensation & 200 & 6 & 25 & 15.73 & 4.626 \\
\hline $\begin{array}{l}\text { Employees' Job } \\
\text { Performance }\end{array}$ & 200 & 7 & 24 & 16.23 & 4.823 \\
\hline $\begin{array}{l}\text { Valid N } \\
\text { (listwise) }\end{array}$ & 200 & & & & \\
\hline
\end{tabular}

Source: Primary Data

\subsection{Chi-Square}

This test is administered to ascertain the association between the personal factors and job performance of the employees.

No Association - NA and Association-A

Table III

\begin{tabular}{|c|c|c|c|}
\hline Personal factors & $\begin{array}{c}\text { Chi-Square } \\
\text { Value }\end{array}$ & $\begin{array}{c}\mathrm{P} \\
\text { value }\end{array}$ & NA/A \\
\hline Gender & 70.228 & 0.000 & $\mathrm{~A}$ \\
\hline Age & 27.529 & 0.001 & $\mathrm{~A}$ \\
\hline $\begin{array}{c}\text { Educational } \\
\text { qualification }\end{array}$ & 26.741 & 0.001 & $\mathrm{~A}$ \\
\hline Job position & 68.938 & 0.000 & $\mathrm{~A}$ \\
\hline Experience & 29.993 & 0.000 & $\mathrm{~A}$ \\
\hline Income & 72.135 & 0.000 & $\mathrm{~A}$ \\
\hline
\end{tabular}

Source: Primary Data

It is evident from the above table that hypothesis 3 is accepted in all cases. It is thus concluded that gender, age educational qualification, job position, experience and income are positively associated with the performance of the employees.

\subsection{Correlation}

It was performed to find out the pair wise relationship between the following variables.

JD : Job Design;

TD : Training and Development;

M : Motivation;

SS : Supervisory Support;

WE : Work Environment;

C : Compensation;

EJP : Employees' Job Performance.

$\mathrm{V}$ : Variables

Table IV: Correlation Matrix for HR Practices and Employees' Job Performance

\begin{tabular}{|l|r|r|r|r|r|r|r|}
\hline $\mathrm{V}$ & \multicolumn{1}{|c|}{$\mathrm{JD}$} & $\mathrm{TD}$ & $\mathrm{M}$ & $\mathrm{SS}$ & $\mathrm{WE}$ & $\mathrm{C}$ & $\mathrm{EJP}$ \\
\hline $\mathrm{JD}$ & 1 & & & & & & \\
\hline $\mathrm{TD}$ & $.894^{*}$ & 1 & & & & & \\
\hline $\mathrm{M}$ & $.908^{*}$ & $.867^{*}$ & 1 & & & & \\
\hline $\mathrm{SS}$ & $.782^{*}$ & $.689^{*}$ & $.739^{*}$ & 1 & & & \\
\hline $\mathrm{WE}$ & $.873^{*}$ & $.707^{*}$ & $.817^{*}$ & $.672^{*}$ & 1 & & \\
\hline $\mathrm{C}$ & $.932^{*}$ & $.879^{*}$ & $.862^{*}$ & $.658_{*}^{*}$ & $.866_{*}^{*}$ & 1 & \\
\hline $\mathrm{EJP}$ & $.893^{*}$ & $.760^{*}$ & $.820_{*}^{*}$ & $.658^{*}$ & $.921_{*}^{*}$ & $.871_{*}^{*}$ & 1 \\
\hline
\end{tabular}

Source: Primary Data

**. Correlation is significant at the 0.01 level (2-tailed).

The above shows that the factors JD, TD, M, SS, WE and $\mathrm{C}$ are independently positively correlated with EJP and also highly significant at $1 \%$ level. Therefore, $\mathrm{H} 1$ of the present 
study is accepted. Here it is obvious that the maximum correlation $(\mathrm{r}=0.921)$ is existing between WE and EJP, followed by the association $(\mathrm{r}=0.893)$ between JD and EJP; $\mathrm{C}$ and EJP $(r=0.871) ; \mathrm{M}$ and EJP $(\mathrm{r}=0.820)$, TD and EJP $(\mathrm{r}=$ $0.760)$ and SS and EJP $(r=0.658)$. HR practices are pairwise positively significant at $\mathrm{P}$-value 0.000 . Among the six practices the relationship between the $\mathrm{C}$ and JD $(r=0.932)$ is the highest, followed by the link between $\mathrm{M}$ and JD ( $\mathrm{r}=$ 0.908).

\subsection{Regression}

Let the dependent variable, employees' job performance be denoted by $\mathrm{z}$

Let the independent variables are job design, compensation, motivation, working environment, training and development and supervisory support be denoted by $\mathrm{x} 1, \mathrm{x} 2$, $\mathrm{x} 3, \mathrm{x} 4, \mathrm{x} 5$ and $\mathrm{x} 6$ respectively.

$\mathrm{z}=\mathrm{f}$ (job design, compensation, motivation, working environment, training and development and supervisory support $)=\mathrm{f}(\mathrm{x} 1, \mathrm{x} 2, \mathrm{x} 3, \mathrm{x} 4, \mathrm{x} 5, \mathrm{x} 6)$

$\mathrm{z}=\mathrm{f}(\mathrm{x} 1, \mathrm{x} 2, \mathrm{x} 3, \mathrm{x} 4, \mathrm{x} 5, \mathrm{x} 6)$

Also let

$\mathrm{Z}=\mathrm{a}+\mathrm{b} 1 \times 1+\mathrm{b} 2 \times 2+\mathrm{b} 3 \times 3+\mathrm{b} 4 \times 4+\mathrm{b} 5 \times 5+\mathrm{b} 6 \times 6+\mathrm{e}$

Where $\mathrm{a}=$ parameter of regression model

$\mathrm{b}=$ Coefficients

$\mathrm{X}=$ Independent Variables

$\mathrm{e}=$ Standard Error

a. Predictors: (Constant), are job design, compensation, motivation, working environment, training and development and supervisory support

b. Dependent Variable: Employees' job performance

\section{Table V}

\begin{tabular}{|c|c|c|c|}
\hline Model & Variables Entered & $\begin{array}{c}\text { Variables } \\
\text { Removed }\end{array}$ & Method \\
\hline 1 & $\begin{array}{c}\text { JD, TD, M, SS, WE, } \\
\mathrm{C}^{\mathrm{a}}\end{array}$ & & Enter \\
\hline
\end{tabular}

a. All requested variables are entered

b. Dependent Variable: EJP

Table VI: Model Summary

\begin{tabular}{|c|c|r|r|r|}
\hline Model & $\mathrm{R}$ & $\begin{array}{c}\mathrm{R} \\
\text { square }\end{array}$ & $\begin{array}{c}\text { Adjusted } \\
\mathrm{R} \\
\text { Square }\end{array}$ & $\begin{array}{c}\text { Std. Error of } \\
\text { the Estimate }\end{array}$ \\
\hline 1 & $.941^{\mathrm{a}}$ & .886 & .882 & 1.657 \\
\hline
\end{tabular}

a. Predictors: (Constant), JD, TD, M, SS, WE and C

Table VII: ANOVA

\begin{tabular}{|c|l|r|r|r|r|r|}
\hline \multicolumn{2}{|l|}{ Model } & \multicolumn{1}{c|}{$\begin{array}{c}\text { Sum of } \\
\text { Squares }\end{array}$} & \multicolumn{1}{c|}{ df } & $\begin{array}{c}\text { Mean } \\
\text { Square }\end{array}$ & \multicolumn{1}{c|}{ F } & Sig. \\
\hline \multirow{3}{*}{1} & Regression & 4099.541 & 6 & 683.257 & 248.865 & .000 \\
\cline { 2 - 8 } & Residual & 529.879 & 193 & 2.745 & & \\
\cline { 2 - 8 } & Total & 4629.420 & 199 & & & \\
\hline
\end{tabular}

a. Predictors: (Constant), JD, TD, M, SS, WE and C

b. Dependent Variable: EJP
Total variation $=$ total $=\sum(\bar{y}-y)^{2}=4629.420$

Error of variation $=$ residual $=\mathrm{SSE}=\sum(y-y 1)^{2}=529.879$

Regression variation $=\mathrm{SSR}=\mathrm{SS}$ total $-\mathrm{SSE}=4629.420$ $529.879=4099.541$

\section{$\mathrm{P}$ value $=<0.001^{* *}$}

The HR practices (JD, TD, M, SS, WE and C) in the above model revealed the ability to predict EJP $\left(R^{2}=0.886\right)$. In this model, the value of $\mathrm{R}^{2}$ denotes that $88.6 \%$ of the observed variability in EJP can be significantly explained by the HR practices namely JD, TD, M, SS, WE and C. The remaining $11.4 \%$ is not explained which means that the rest $11.4 \%$ of the variation of EJP is related to other variables which are not depicted in this model. This variance is highly significant as indicated by $\mathrm{F}$ value $\left(\mathrm{F}=248.865\right.$ and $\left.\mathrm{P}=0.001^{* * *}\right)$. The ANOVA table indicates that most possible combination of predictor variables that could contribute to the relationship with the dependent variable.

Table VIII: Coefficients of Predictors of EJP

\begin{tabular}{|c|c|c|c|c|c|c|}
\hline \multirow{2}{*}{\multicolumn{2}{|c|}{ Model }} & \multicolumn{2}{|c|}{$\begin{array}{c}\text { Unstandardized } \\
\text { Coefficients }\end{array}$} & \multirow{3}{*}{$\begin{array}{c}\begin{array}{c}\text { Standardized } \\
\text { Coefficients }\end{array} \\
\text { Beta }\end{array}$} & \multirow{3}{*}{$\begin{array}{c}\mathrm{t} \\
3.215 \\
\end{array}$} & \multirow{3}{*}{$\begin{array}{l}\text { Sig. } \\
.002 \\
\end{array}$} \\
\hline & & \multirow{2}{*}{$\begin{array}{c}\text { B } \\
2.096 \\
\end{array}$} & \multirow{2}{*}{$\begin{array}{r}\begin{array}{c}\text { Std. } \\
\text { Error }\end{array} \\
.652 \\
\end{array}$} & & & \\
\hline \multirow{7}{*}{1} & (Constant) & & & & & \\
\hline & JD & .425 & .100 & .431 & 4.240 & .000 \\
\hline & TD & .037 & .065 & .039 & .563 & .574 \\
\hline & M & -.030 & .063 & -.030 & -.474 & .636 \\
\hline & SS & -.128 & .062 & -.085 & -2.048 & .042 \\
\hline & WE & .584 & .059 & .608 & 9.946 & .000 \\
\hline & $\mathrm{C}$ & -.010 & .086 & -.009 & -.111 & .912 \\
\hline
\end{tabular}

Dependent variable: EJP

Source: Primary data

The regression equation is:

Employees' Job Performance $=2.096+0.425 \times 1+0.037 \times 2$ -

\section{$0.030 \times 3-0.128 \times 4+0.584 \times 5-$ $0.010 \times 6+\mathrm{e}$}

The above table shows that JD, TD and WE are positively affecting the dependent variable EJP (direct relationship with EJP) as the beta value for JD $=0.425$; $\mathrm{TD}=0.037$ and for $\mathrm{WE}$ $=0.584$. If $\mathrm{JD}, \mathrm{TD}$ and $\mathrm{WE}$ increase the job performance of employee also increases. But M, SS and C are negatively affecting the dependent variable EJP (indirect relationship). Based on the $\mathrm{P}$ value, the independent variables JD, SS and WE are having a positive and significant relationship with the dependent variable at $1 \%$ and $5 \%$ level, but TD, $\mathrm{M}$ and $\mathrm{C}$ are not having a significant relationship at 5\% level. On the basis of above analysis, hypotheses 4,7 and 8 are accepted but hypothesis 5, 6 and 9 has been rejected. Hence the hypothesis 2 is moderately accepted. 


\subsection{Friedman Test}

Table IX

\begin{tabular}{|l|r|r|r|}
\hline \multicolumn{1}{|c|}{ HR factors } & Mean Rank & $\begin{array}{c}\text { Chi-square } \\
\text { value }\end{array}$ & $\begin{array}{c}\text { P } \\
\text { value }\end{array}$ \\
\hline Job Design & 3.54 & & \\
\cline { 1 - 2 } $\begin{array}{l}\text { Training and } \\
\text { Development }\end{array}$ & 3.38 & & \\
\cline { 1 - 2 } Motivation & 3.60 & & \\
\cline { 1 - 2 } Supervisory Support & 3.33 & & 0.299 \\
\cline { 1 - 2 } Work Environment & 3.70 & & \\
\hline Compensation & 3.44 & & \\
\hline
\end{tabular}

Source: Primary Data

The above table shows that there is no significant difference between the mean rank and HR factors because the $\mathrm{p}$ value is 0.299 . Therefore we accept Hypothesis 10 at 5\% level. The most important HR factor that affects employees' job performance is WE (3.70) followed by $\mathrm{M}(3.60)$, $\mathrm{JD}(3.54)$, C (3.44), TD (3.38) and SS (3.33).

\section{CONCLUSION}

The study reveals that there is a very strong positive relationship between HR practices and employees' job performance. From the correlation matrix, highest positive value of correlation ascending between WE, JD, C, M, TD and SS which clarifies that the Leather Industries at Vellore district are required to focus on these HR practices for getting fabulous employees' job performance. From the Regression model, it is clear that the high performance HR practices have a moderate impact on employees' job performance. From the Friedman test, it is found that work environment is the significant HR practice that affects employees' job performance followed by motivation, job design, compensation, training and development and supervisory support.

\section{Policy Implications}

It is apparent that HR practices in Leather Industries have not been copiously established, it may be appropriate to state briefly the policy implications for the study to enhance the performance of the employees in the organization. The organization should provide employees with proper and favourable work environment which includes health, safety and welfare facilities according to the satisfaction of the employees to work with peace and joy. The compensation should be provided after the proper analyses of performance of the employees by adopting true, fair and effective method. Effective training and development techniques should be adopted to improve the performance of the employees and to avoid accident. Motivational rewards to be provided which initiates the employees to work with enthusiasm and involvement. The supervisors should treat the employees as a protégé which supports them greatly to build their career.

\section{REFERENCE}

[1] O.I. Adeniyi, "Staff training and development", Training Needs Analysis: A resource for identifying training needs, selecting training strategies, and developing training plans, 2nd Edition, Aldershot, Gower, 1995.

[2] M. Armstrong, "A Handbook of Human Resource Management Practice", London \& Philadelphia, Kogan Page Ltd, 10 ${ }^{\text {th }}$ edition, 2006.
[3] K. Bachmann, "Health Promotion Programs at Work: A Frivolous Cost or a Sound Investment?", Ottawa: Conference Board of Canada, 2002.

[4] H.K. Bernadin, J.S. Kane, S. Ross, J.D. Spina, and D.D. Jonhson, "Performance appraisal design, Development and implementations", Handbook of human resource management, 1995.

[5] P. Brenner, "Workers physical surrounding and Impact Bottom Line Accounting", Smarts Pros.com, 2004.

[6] L. J. Cronbach, "Coefficient alpha and the internal structure of test", Psychometrika, 16(3), Pp. 297-334, 1951.

[7] David Devins, Steve Johnson, John Sutherland, "Employer characteristics and employee training outcomes in UK SMEs: a multivariate analysis", Journal of Small Business and Enterprise Development, Vol.-11 Iss: 4, Pp.449 - 457, 2006

[8] K. Datta, J. Guthrie, P. Wright, "HRM and Firm productivity: Does industry matter", National Academy of Management Meetings, WA, 2003.

[9] G. Dessler, "Human Resource Management", Prentice Hall of India Private Ltd., New Delhi, $11^{\text {th }}$ edition, 2008.

[10] R. Donald, Cooper and Ramcis, S. Schindler, "Business Research Methods", Tata McGraw Hill Publishing Company Limited, New Delhi, 2000.

[11] L. Dyer, T. Reeves, "HR strategies and firm performance: what do we know and where do we need to go?" International Journal of Human Resource Management, 6:3, Pp. 656-670, 1995.

[12] A.R. Elangovan, \& J.L. Xie, "Effects of perceived power of supervisor on subordinate stress and motivation: The moderating role of subordinate characteristics", Journal of Organizational Behavior, Iss: 20(3), Pp.359-373, 1999.

[13] C. Gómez, \& B. Rosen, "The leader-member exchange as a link between managerial trust and employee empowerment", Group\& Organization Management, Iss:26(1), Pp. 53-69, 2001.

[14] D. Guest, "Human Resource Management, Corporate Performance and Employee wellbeing: Building the worker into HRM", The Journal of Industrial Relations, Iss: 44:3, Pp. 335-358, 2002.

[15] J.R. Hackman and G.R. Oldham, "Development of the Job Diagnostic Survey", Journal of Applied Psychology, Iss:60, Pp.159-170, 1975.

[16] M.A. Huselid, "The impact of human resource management practices on job performance", Academy of Management Journal, 1995.

[17] N.K. Malhotra, "Marketing research: an applied orientation", Pearson Education Asia, New Delhi, India, $2^{\text {nd }}$ Edition, 2000.

[18] H.H.D.N.P. Opatha, "Performance Evaluation of Human Resource", The Author publication, Colombo, Sri Lanka, Pp.2-12,170-183, 1st Edition 2002.

[19] J. Pfeffer, "Competitive advantage through people: Unleashing the power of the work force", Harvard Business School Press, Boston, 1994.

[20] L. Robert and H. Arocas, "A model of high performance work practises and turnover intentions", Personnel Review, Pp.37, 26-46, 2007

[21] M. H. Strong, P.R. Jeannerert, S.M. McPhail\& B.R. Blackley, "Work context, taxonomy and measurement of the work environment", American Psychological Association (Houston TX), 86 : 12767, 1999.

[22] O. Shadare, A. Hammed and Ayo, "Influence of work motivation, leadership effectiveness and time management of employees' performance in some selected industries in Ibadan", European Journal of Economics, Finance and Administrative Science, Oyo State, Nigeria, vol. 1450-2887, no. 16, Pp. 7-17, 2009.

[23] tidco.com, 2006.

[24] P. Wright, T. Gardener, L. Moynihan L, "The Impact of HR practices on the performance of business units", Human Resource Management Journal, 2003,

[25] B. William, Jr. Werther, K. Davis, "Human Resource and Personnel Management", McGraw-hillInc, $5^{\text {th }}$ edition, 1996.

[26] P.K. Zinghein, "Rewarding scarce talent", The compensation handbook, A state of the art guide to compensation strategy and design, McGraw Hill, New York, $4^{\text {th }}$ edition, 2000. 